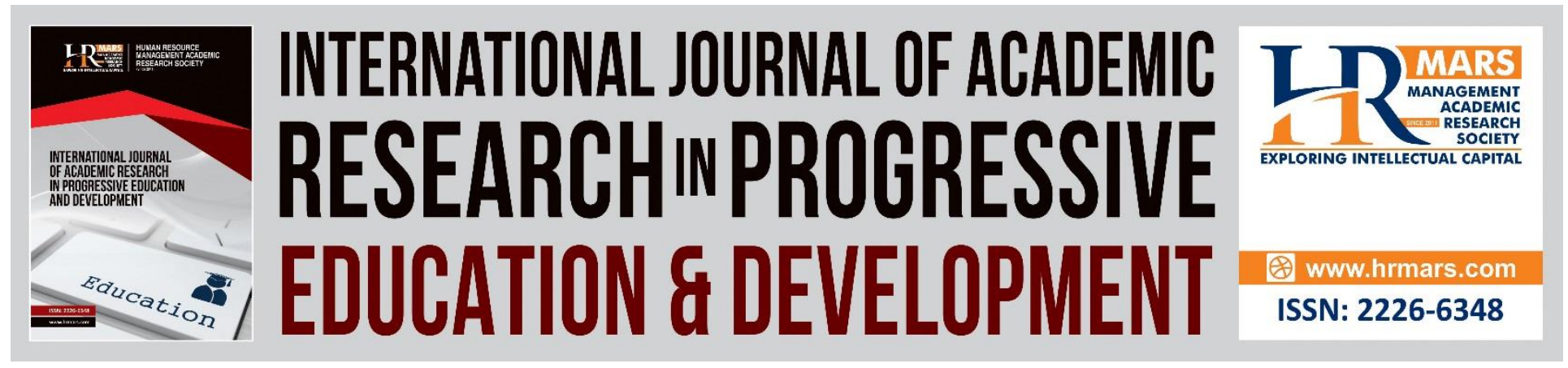

\title{
Implementation Critical Thinking in Teaching Islamic Education
}

Aminurrashid Ahmad Dahari, Asmawati Suhid, Fathiyah Fakhrudin

To Link this Article: http://dx.doi.org/10.6007/IJARPED/v8-i4/6756

DOI:10.6007/IJARPED/v8-i4/6756

Received: 15 November 2019, Revised: 30 November 2019, Accepted: 11 December 2019

Published Online: 30 December 2019

In-Text Citation: (Dahari et al., 2019)

To Cite this Article: Dahari, A. A., Suhid, A., \& Fakhrudin, F. (2019). Implementation Critical Thinking in Teaching Islamic Education. International Journal of Academic Research in Progressive Education and Development, 8(4), 805-823.

Copyright: (C) 2019 The Author(s)

Published by Human Resource Management Academic Research Society (www.hrmars.com)

This article is published under the Creative Commons Attribution (CC BY 4.0) license. Anyone may reproduce, distribute, translate and create derivative works of this article (for both commercial and non-commercial purposes), subject to full attribution to the original publication and authors. The full terms of this license may be seen

at: http://creativecommons.org/licences/by/4.0/legalcode

\section{Vol. 8(4) 2019, Pg. 805 - 823}

Full Terms \& Conditions of access and use can be found at http://hrmars.com/index.php/pages/detail/publication-ethics 


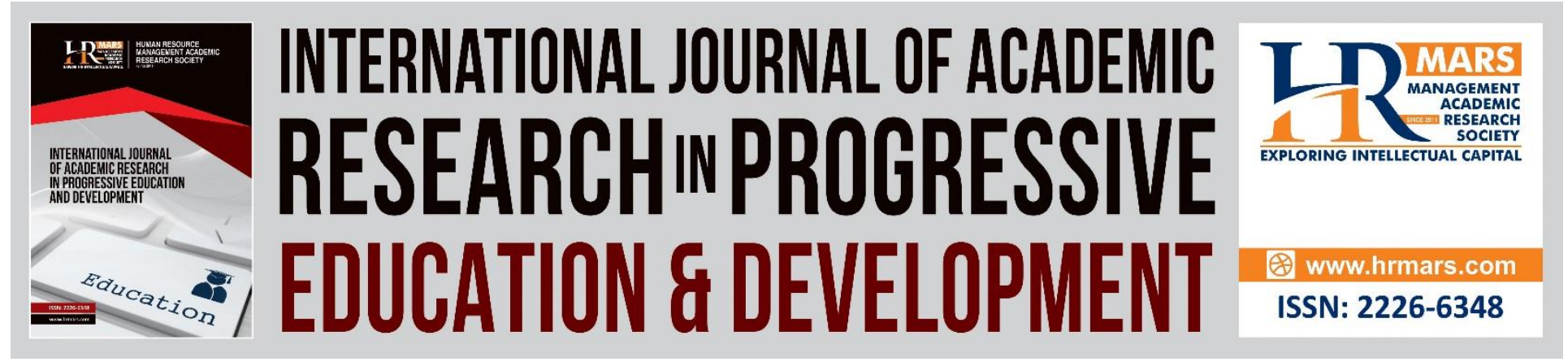

\title{
Implementation Critical Thinking in Teaching Islamic Education
}

\author{
Aminurrashid Ahmad Dahari, Asmawati Suhid, Fathiyah \\ Fakhrudin
}

Faculty of Education Studies, University Putra Malaysia, 43400 Serdang, Selangor, Malaysia

\begin{abstract}
Critical thinking is a worth skill inculcate pure thought in teaching Islamic Education exclusively to enhance meaningful learning outcomes. These elements of critical thinking need to be integrated into the process of knowledge acquisition by teachers so that students can get deep understanding and make appropriate judgments when dealing with specific situations in life. In this research, an analytical research being used to apply critical thinking framework which built based on the theory and approach of Critical Thinking Models according to Islamic Epistemology. In addition, technology integration and supportive learning environment conducive to providing a practical framework. These results create collaborative interactions that will focus on assessing student achievement in all aspects. Clarification of this thinking framework can provide a more active and effective teaching and learning environment. This critical thinking framework can be applied based on seven steps involved. These include student-centred strategies, discussion methods, questioning and feedback techniques, integration and synthesis of information and coming up with new ideas. This conceptual paper concludes that teaching applies critical thinking can shed light on some of the most profound and meaningful features of teaching. The implications also suggest some additional teachers' basic skills such as conceptual and procedural skills, inquiry, logic and Mantik. All these skills and competencies empowerment the credibility and capacity of teachers whom being consistently in developing high-level thinking skills in 21st century pedagogy.
\end{abstract}

Keywords: Critical Thinking, Instruction, Islamic Education, Teacher

\section{Introduction}

Competency in cognitive skills is important in teaching and learning process. One of the skills that needs to be mastered is thinking skills. This skill can enhance students' knowledge of the content and problem-solving solutions (Rosnani, 2013). This can be realized when students are able to relate what they have learned to the current context and environment. In fact, these cognitive skills are also capable of proving true, accurate, and relevant thinking. Therefore, teachers should be prepared with a curriculum that is equipped with critical thinking skills to be 
able to justify the truth. An Islamic education teacher needs to be more skilled and capable of implementing an appropriate and effective teaching to enhance students' cognitive and affective abilities. This is because the aim of Islamic education is to uphold the dignity of science and intelligence, as well as the vision towards culture and values that requires a high level of thinking (Asmawati, Aderi, Muhsin, \& Khadijah, 2016). This is in line with the efforts to capitalize on Islamic education through the Malaysian Education Development Plan (PPPM) 2013-2025 (KPM, 2013) that spark the 21st century learning. Clearly state that the efforts and implementation of strengthening Islamic education at the school level have become the agenda for the future.

The curriculum drafting today has absorbed the elements of the 21st Century Skills, High Orders Thinking Skills (HOTS), and pedagogical skills. All components are explicitly included in the Islamic Education curriculum document (DSKP) for the human capital required to meet future needs. Among the aspects contained in one of the objectives are to develop and enhance the intellectual, critical, and creative thinking (Ministry of Education Malaysia, 2017). This means that critical thinking is an important element of value added in teaching and learning.

\section{Critical Thinking in Thinking Skills}

In determining the focus of this writing, critical thinking skills should be emphasized as they have the potential to help improve the quality of student learning. Scriven and Paul (1992) explain that critical thinking skills are an intellectually active and disciplined process. The process includes activities such as conceptualization, application development, analysis, synthesis, and evaluation of information collected. For example, this form of skill is based on accuracy, precision, depth, consistency, and relevance. It involves the structure or element of implicit thinking in all reasoning, namely the goals, problems, assumptions, concepts, and empirical training that leads to conclusions, implications, and consequences.

The main function of critical thinking is the ability to analyze and the second is to evaluate information. Analytical skills are critical in improving understanding and ability to use existing information. Meanwhile, critical assessment skills can explore the validity of an idea (Azizi, Noordin \& Zurihanmi, 2005; Yahya, Razali, \& Baki, 2018; Sorunke, 2018)

The two critical thinking activities include asking important questions and issues, formulating clearly, and collecting and evaluating relevant information using abstract ideas, thinking with open minds, and communicating effectively.

In addition, Mulnix (2012) conceptualizes critical thinking as the ability to pilot, master, and develop the ability to perceive affinity or symbiosis. The interplay between the existing references and the interrelated relationships produces alternative solutions to complexity and complex lives. Cederblom and Paulsen (2011) emphasize that someone who can master critical and creative thinking skills can stimulate analytical input in order to analyze an issue. In addition, critical thinking is needed in order to shed light on the issue. The ability to structure, develop sentences, and deconstruct supporting evidence is a must-have. Therefore, educators should be trained to improve their critical thinking skills by considering the various references and inputs available in the environment.

From the above discussion, critical thinking is selected as an important medium to enhance teacher's teaching in the classroom. Teachers need to master critical thinking so that the learning and teaching process can achieve the goals and objectives that have been set more 
Vol. 8, No. 4, 2019, E-ISSN: 2226-6348 @ 2019 HRMARS

effectively and effectively. The determination of critical thinking as the core of thinking skills in this study shows its significance in various fields of study especially Islamic education.

\section{Critical Thinking in Islamic Education}

The Islamic approach in thinking is based on the paradigm of monotheism and manners. This paradigm emphasizes the value of seeking the truth based on the guidance of revelation (Hisham, 2014). Pedagogical thinking skills, emphasizing on cognitive, affective, and psychomotor teaching had contributed to a positive effect on students (Norfadelah \& Ahmad, 2015). Thus, the Islamic Education subjects were excluded from the field of teaching and learning in developing students' potential in critical thinking. This means that the Islamic education teachers should be able to master the skills of thinking, analyzing, and synthesizing. The aspects of effective teaching of the Islamic education should be abounded with true and wise mental activities (Rosnani, 2013). It involves the instinctive desire to seek the truth, to deepen understanding, to ponder the future, to propose solutions, to delve into the complexities, and to deal with the complexities and complexities of complex human life. Thus, critical thinking works to get rid of misunderstandings and to seek for the absolute truth in adapting to a difficult environment. Critical thinking is an initiative that is in line with the human nature as the meaning of the Qur'an suggests:

"Behold! in the creation of the heavens and the earth, and the alternation of night and day,- there are indeed Signs for men of understanding Ulu Albab Men who celebrate the praises of Allah, standing, sitting, and lying down on their sides, and contemplate the (wonders of) creation in the heavens and the earth, (With the thought)." (Ali Imran verse 190-191)

The above quotation clearly shows that the Qur'an emphasizes the importance of thinking among scholars to constantly observe, analyze, and make critical comparisons to the universe. Furthermore, Norfadelah's and Ahmad's (2015) study summarizes and elaborates on Dr. Yusuf al-Qaradawi's perspective which highlights some of the key features of scientific thinking:

"Independent and objective scientific reasoning and rejecting heresy, heresy and heresy. Essentials of the "scientific intellect" according to al-Qaradawi are to reject doubt in certain matters, not to lust and emotion in the field of science, to reject the blind claim to heritage ancestors, not submissive or obsessed with leaders. In addition, the use of common sense or thought in matters that are allowed and not affected by any exclamation or prayer has no evidence or evidence." (Norfadelah \& Ahmad, 2015)

The argument above shows that the Qur'an affirms the use of intellect based on definite and conclusive proofs. The information and knowledge gained through ranking is for the benefit and well-being of the people and intellectual development in education. Therefore, research on critical thinking in Islamic education should be generated based on the thinking of prominent Islamic leaders. Some of the leading figures, such as Abdullah Nashih Ulwan, Ibn Qayyim al Jawziyyah, and others have been able to enlighten the critical thinking of teachers in teaching Islamic education. The essence of the book of Tarbiyatul Aulad Fil Islam (Abdullah, 2012), 
emphasizes that early education is a key element in addressing three important elements of Islam: faith, morality, and worship. All these elements highlight the importance of basic education that needs to be strengthened (Abdullah, 2012). However, not many attempts to articulate such thoughts or attitudes are reflected in the learning environment in line with the current demands. In fact, their great ideas and works based on the accuracy of the Qur'anic knowledge and the relevance of the current evidence based on As Sunnah can provide a relevant and an effective tarbiah. It clearly shows that capability to inculcate the ability and inclination of the teacher's mind needs to be an effective teacher (murabbi).

If observed, it appears that the definition and meaning of "scientific mind" in Dr. Yusuf alQaradawi's perspective is broader and is also an integral part of the concept of critical thinking. Furthermore, knowledge coupled with the power of the intellect will be able to help identify people with His creation, glorify Him, and thus give birth to ubudiyyah (al-Ghazali, 2007). Another benefit that can be achieved is the ability to produce mindfulness with a fair and equitable solution. It can be concluded that the importance of critical skills in teaching especially in Islamic education should be developed so that students can lead a more prosperous life. The next one can appreciate the content of knowledge and new application that is meaningful teaching.

Thus, the teaching of Islamic education teachers should also be a catalyst that promotes a critical, creative, and innovative thinking culture. This can be done through the Primary School Curriculum (KSSR) and the Secondary School Curriculum (KSSM) to integrate various disciplines. Even the Islamic perspective of critical thinking states that the goal is to find the truth in every matter and to reject falsehood. This effort must be rooted in the true source and also based on the Divine guidance provided in the Qur'an and the Sunnah (the main normative source of Islam) on rights. If these criteria are not met, then it cannot be considered legitimate from an Islamic perspective (Mumtaz, 2008).

\section{Strategies and Approaches in Instruction to Promote Critical Thinking}

One of the efforts and approaches to promote critical thinking is inclusion or integration. These are a process that incorporates the skills of thinking skills in teaching and learning activities $(\mathrm{PdPc})$. Activities that encourage the integration of elements of high-level thinking skills should be integrated into teaching strategies (Aida, 2016). However, the developments on Islamic Education teaching had focused solely on one of the ways in which these perceptions do not have a positive impact on students' thinking skills. For example, lectures using teacher-centered strategies are often used in teaching Islamic education (Hatifah, 2000). This does not help in raising critical thinking as students become passive and seem to be the only teacher in question, doing inquiry and thinking about the subject being taught (Maiorana, 1991). In contrast, active learning makes the learning environment more enjoyable and most importantly, it can engage students in critical thinking. In fact, students' confidence will improve as they continue to study a subject more enthusiastically and motivatedly.

In order to benefit students, teachers need to provide many opportunities for them to engage in each level of discussion in a cohesive way including the high and low levels of Bloom's Taxonomy where critical thinking takes place. Even teachers believe developing critical thinking among them is very important (Albrecht \& Sack, 2000), but only a few have ideas on how to teach them or how they should be evaluated (Paul, Elder, \& Batell, 1997). The model in Figure 1 is a 
Vol. 8, No. 4, 2019, E-ISSN: 2226-6348 @ 2019 HRMARS

seven-step framework that can be implemented in any learning and training class. It then becomes the catalyst in learning to move the critical thinking process towards thinking skills based on arguments in Islam.

\section{Methods}

A qualitative research that emphasizes on the empirical analysis of various scientific sources consisting of theories, scientific texts, and published journals has been used in this conceptual paper.

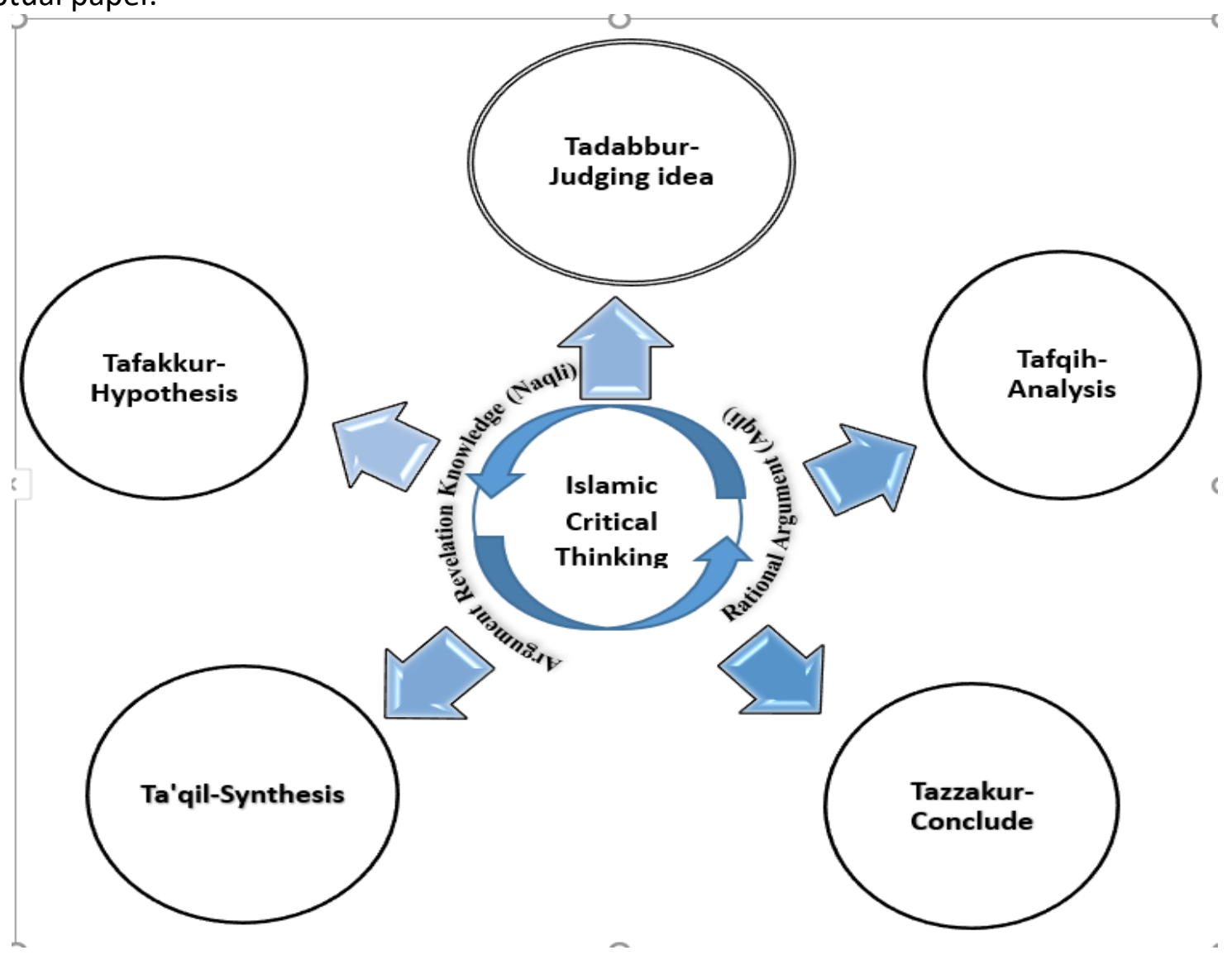

Figure 1. Critical Thinking Models Based Islamic Epistemology

(Source: Norfadelah \& Ahmad, 2015)

The conceptual framework of this critical thinking element is adapted from the framework of the Thinking Skills model by Norfadelah \& Ahmad (2015) which emphasizes on Islamic principles that are equilibrium and holistic.

Based on Figure 1 above, critical thinking concepts should be based on sources and arguments as well as arguments based on revelation and reason. These two sources of epistemology are important to nurture in critical thinking. This is because the intellectual power in Islam not only provides a valid and absolute argument but must also emphasize the elements of wisdom and civilization (Othman \& Hashim, 2006). All five processes in the basic cycle of critical thinking meet the definition of critical thinking according to Scriven and Paul (1992), but all must be based on arguments and evidence from the Islamic reasoning and revelation. Thus, Islamic 
education teachers should play a clear role in the proposition of correct arguments and can relate them to current issues to generate a dynamic and an active discussion.

According to the opinions expressed by Qader et al (2012), the "Bloom's taxonomy is a framework for analyzing and testing levels of assessment in learning." The Islamic approaches provide a holistic view of knowledge and enlightenment in deeper ways. It covers all levels until it synthesizes and tests the highest level of knowledge, and this is known as the science of conscience. The objective of conscience is to enable one to understand the Islamic perspective as the core, and then, the second nucleus is the Tauhîd principle that motivates all within the framework of thought. Islam (Muhammad, 2011).

Students who think critically need to test and evaluate whether or not a reason is relevant and applicable based on agreed criteria or values. Therefore, the use of various reasoning strategies in the implementation of these criteria or standards and seeking information is a credible evidence to support the decision made (Rudd, Baker, \& Hoover, 2000). Students who are taught to think critically need to learn how and when to ask questions and what kind of questions to ask, and to learn how to reason, which it is applicable when using reasoning and the method of reasoning to apply (Fisher, 2001).

However, critical thinking frameworks according to Islam do not reject low-level thinking. For example, in other areas students only need to do memorization and application, but higherlevel thinking such as analysis and creation is not required. However, the process of integrating Islamic Education PdPc with conscience requires all levels and stages of learning to be a subterranean thinking. This is because Islamic philosophy refers to the unity and integrity of knowledge. Whereas keywords related to Islamic critical thinking refer to the basic form and depth and focus of a search for knowledge and knowledge based on Islamic epistemology namely the arguments or explanations of revelation and the arguments of reason. Zainoriah (2015) explains that the concept of critical thinking according to the Qur'anic reference should serve as a guide for establishing true belief and faith, namely to direct Allah s.w.t.

\section{The Implementation of Teacher's Critical Thinking in Instruction}

The role of Islamic Education teachers in implementing critical thinking in teaching is one of the responsibilities of the teaching profession. Critical thinking can be applied in teaching which includes aspects of strategy, approach and content and assessment. Somehow, before teachers can implement these critical thinking, they need to have enough resources. That involves the preparation of appropriate strategies and approaches with needs effective teaching implementation. Aspects of pedagogy, assessment, and learning environment need to be aligned with the integration of critical thinking into teaching. Teacher's preparation also needs to include both the content knowledge (conceptual knowledge) and pedagogical content knowledge (procedural knowledge) in order to achieve the goal of mastering the thinking skills. As a skilled teacher, the application of measures should be carefully planned as a guide that facilitates the implementation of critical thinking in the teaching of Islamic education.

Teachers need to continually work on deepening the content of their knowledge to ensure that their teaching techniques help students to develop critical thinking skills. In addition to the teacher's competence, teachers also need to monitor classroom activities closely by tracking student engagement in their teaching diaries and reflection journals. Knowing and recognizing 
students' backgrounds in detail can provide a fair assessment. Other reflective comments can also be found in these journals of theirs, and this can be very useful when reviewing or updating teaching activities.

In initiating the critical thinking process, the steps of arbitration as well as examining the arguments and ideas contained in these diagrams facilitate the procedure and layout of the action level ranking. All these steps are practical, and they lead to the reflective thinking of students and teachers. A very useful framework for enhancing students' thinking skills and strengthening the teaching methodology strategy. Efforts to promote critical thinking can be achieved through any content rating with customized lecture modifications and easy integration of active learning techniques. The following are the seven critical thinking steps that teachers can take to be more systematic and structured in implementing critical thinking in their teaching as shown in Figure 2. 


\section{Step 1: Establish Learning Objectives}

* Explain the behavior that should be shown

* Target behaviors that use high-level thinking

Step 2: Encourages Questioning behavior

* Develop appropriate questioning \& Apply questioning techniques.

* Encourage interactive discussions

Step 3: Active Learning Before Evaluation

* Choose active learning activities

* Includes all active learning components

$\begin{array}{r}\text { Step 4: } \quad \text { Review and Validation Idea } \\ \begin{array}{r}* \text { Identify validity \& validity } \\ * \text { Secure and verify content \& facts }\end{array} \\ \hline\end{array}$

\section{Step 5: Integrating \& Formulating ideas}

* practice knowledge through logic (logic)

* Integrate with critical ideas and Integrasi \& Formulate ideas \& Information

\section{Step 6: Provide critical learning feedback and assessment}

* use feedback (self-reflection) to improve teaching

\section{Step 7: Suggest new concepts and ideas}

* integrates with epistemology of Islamic science

* triggers new concepts, ideas and solutions

Figure 2. Seven Step Teacher Critical Thinking adaptation from Higher Order Thinking Skills Development Process Models (Limbarch, B.,\& Waugh, W.,1986)

\section{Step 1. Define Learning Objectives}

Determining learning objectives is the first step that teachers need to take. Teachers need to identify the main learning objectives that determine student outcomes and that can be 
observed after teaching in the classroom. These elements of critical thinking can be realized in the learning objectives, learning activities, and assessment according to Bloom's higher taxonomic level (Anderson \& Krathwohl, 2001).

Krathwohl (2002) states that writing good objective frameworks should include behavior that is appropriate to the level chosen according to the taxonomy. This provides the opportunity for teachers to build a foundation of internal motivation and then work diligently and focus. Therefore, the planned lesson plans should target specific behaviors and enable the desired behavior, as well as end with the pupil's behavioral response (Krathwohl, 2002). The formulation of appropriate level questions should be formulated well in the teaching strategies and enable students to develop critical thinking skills. The learning objectives should also be based on the Student Success Index as stated in the Curriculum and Assessment Standard (DSKP) document. The document explains the need for teachers to align the content standards, learning standards, and performance standards with the teaching and learning objectives (CPC, 2017). The role of the teacher is therefore to ensure that the objectives of teaching are aligned with the subject of Islamic education and the intellectual level of the student.

In conclusion, critical thinking teachers need to ensure a careful planning for the attainment of Islamic education goals. Strong collaboration in student-teacher interaction requires a continuous and ongoing relationship. This can mobilize students to uphold and stimulate them to improve their academic and personal achievement, and thus enhance their appreciation of the results.

\section{Step 2. Encourages Questioning Techniques}

Questioning techniques are fundamental to teaching and facilitating. It is an important aspect of the teaching and learning process (Muhammad Azmir, 2012). It enables teachers to create what is known publicly and then develop new ideas and understandings. Questions can be used to stimulate the interaction between teachers and students and to challenge students to defend their explanations and arguments. Clasen and Bonk (1990) state that while there are many strategies that can influence students' thinking, they depend on the depth of the teacher's questions which also have a significant impact. Most student's questions indicate the student's thinking level - the level of knowledge and understanding that is in line with the level of question asked. When teachers plan questions, they need to consider the purpose of each question and then develop the appropriate level and type of questions to achieve that goal. All students need to be given a question-and-answer experience with higher questions. When they become familiar with the use of the teacher's questioning keywords and perceive the whole concept of a teacher's critical thinking, they will regard the teacher an important source of experience.

The focus of the questioning is to be looked at in its entirety, but in this study, the focus is on the analysis, evaluation, and creation stages. According to Duron (2006), based on the Bloom's Taxonomy, the level of analysis requires answers that show the ability to see patterns and apply information, concepts, and theories to component parts. Questions at this level may require students to examine, classify, categorize, differentiate, and analyze. Meanwhile, the rating stage requires answers that show the ability to evaluate evidence based on arguments and reasons. Students at this level can evaluate, critique, recommend, suspect, and evaluate. The final stage of creation requires an answer that demonstrates the ability to combine knowledge of several 
facts and ideas in order to create new or original patterns and concepts. Questions at this level may ask students to integrate, build, create and explore more possibilities.

This shows that questioning techniques can be used to develop thinking among students by asking questions in different categories and ways. One simple method is to use general categories of focus and problem-solving questions (Duron, et al 2006). For example, a teacher can use continuous classroom assessment to enhance and monitor critical thinking of students, whereby students may be asked questions such as "what is the most important thing you learned in class today?" or "what questions are relevant to this session but are most important in your mind?" or "what strategy makes them successful?" Another strategy to inculcate critical thinking is to place students in a group learning situation where they can receive ongoing support and feedback from both teachers and other students.

Among the teaching methods, there are various techniques that emphasize studentcentered approaches. The most important technique for encouraging active student engagement in the classroom is question-and-answer (Nor \& Zamri, 2007). This is understood as something difficult and requires commitment if not planned carefully. Some of the key elements of the questioning skills are as follows: asking simple, concise questions; ready to rearrange questions, build confidence and ready to attract participants and focus; using a variety of techniques; providing feedback and reinforcement without repeated answers, and spreading the question in class.

Designing is a technique widely used by teachers in communicating the facts, concepts, and principles of the field of knowledge as well as enhancing student's thinking. Elder and Paul (1997) suggest that the art of questioning is essential to the survival of learning. If they fail to ask the correct and in-depth questions and provide answers to the questions, students may not be able to take the content seriously. The appropriateness and accuracy of the questions include the compatibility of the questionnaire and the timely and relevance of the content of the discussion and debate. Teachers can and should use deep, contextual questioning techniques to inspire critical thinking in the classroom.

\section{Step 3: Active Learning before Validating}

Most teachers will strive to ensure that active learning is carried out to meet the planned lesson plans. Bonwell and Eison (1991) described active learning as student engagement in activities that made them think about what they were doing. Fink (2003) states that the concept of active learning supports research, showing that students are more knowledgeable and able to retain knowledge longer if they are actively engaged in knowledge. Active learning has a positive impact on a meaningful and an effective learning environment as students tend to be more active and more engaging. To make learning more active, teachers need to learn how to enhance the overall learning experience by adding some types of learning experiences.

There are various strategies that can optimize active learning. A study by Carroll and Leander (2001) states that the use of active learning strategies such as graphic management can enhance students' 'high-level thinking skills as well as enhance students' ability to manage and interpret information. The change in attitude and performance achievement among students can be a measurement of the results of the strategies that have been used. In this regard, the use of active learning strategies in the classroom such as problem-solving exercises, student cooperative 
projects, simulations, case studies, and role play can make teaching and learning more effective (Mayers \& Jones, 1993). This assumes that if an active learning approach is implemented in the Science subjects to enhance student's achievement and interest in Science subjects, then of course it can also be applied to other subjects such as Islamic Education (Ab Halim, 2015). Thus, active learning in classroom teaching and learning can enhance student's achievement, interest, and interaction in Islamic Education subjects.

\section{Step 4: Review and Validation of Idea}

There are two important processes in this fourth step - the review and validation of the content of ideas and information. Teachers can find patterns between incorrect answers or invalid text content and make valid decisions about the decisions that may cause confusion and misunderstandings. These types of activities can also have positive benefits for students. Pupils will be better monitors than their own learning (Duron et al., 2006).

The process of reviewing is to select the most appropriate and closest to the evidence based on the evidence or argument in accordance with the philosophy of Islamic education. This process is also carried out based on the evidence of either the Qur'an or the Hadith (Norfadelah \& Ahmad, 2015). Both processes involve research on an idea or text content. Teachers need to work on the knowledge or source of encyclopaedic books or well-known scholars' books. They need to find and the right source of information, sources that can be trusted and that are able to provide valuable support and benefits. These teacher's actions can enhance their critical skills such as researching, comparing, investigating, and ensuring that only the right can increase their students' confidence in the pursuit of knowledge. This can be implemented more effectively when the teacher understands the logic or Mantik that acts as a filter for the grading of a knowledge. Pupils will be able to see it directly that teachers are concerned about knowledgeprocessing activities in their learning.

\section{Step 5: Integrate and Synthesize Idea and Issue}

At this fifth stage, it requires the process of synthesizing and solving a problem. This is a difficult task because it requires students to have a high level of cognitive involvement involving critical thinking (Anderson \& Krathwohl, 2001). The process of synthesizing is the process of combining different elements to come up with a whole new idea. In addition, synthesis is also the composition of combining ideas, refining ideas, and integrating ideas. Synthesis makes data or information new and integrated, as well as complex (Jeyagobi \& Subramaniam, 2007). Clearly the process in this fifth step should be carefully done.

Among the preparations before the synthesis process is to ensure the ability to gather and connect ideas, facts, and information related to existing knowledge (Duron et al., 2006). Therefore, students need to ensure that they are able to integrate the knowledge and information gained to the best of their ability. Students who have received and understood the information and knowledge presented by the teacher are students who are capable of mastering how to properly integrate knowledge and information. To achieve this level, teachers need to carefully supervise and lead the activity. Using mapping techniques with mind maps is one of the easiest forms of organization in the classroom. At this stage, students will organize the information systematically from the various sources that had been previously selected (Duron et al., 2006). 
Constructing the resulting information is a complex process. Giovanelli (2003) argues that reflective thinking and practice is a cognitive activity that requires the active participation of an individual as a result of an experience that is deeply affecting him or herself through engaging in the testing of beliefs. Giovanelli (2003) claims that thinking about the integration of new insights and experiences that they have had is the key and an important element for them.

The results obtained from the synthesis of knowledge are used as catalysts for students to evaluate their learning and thus engage students in learning the practices that can enhance their thinking ability (Mohd Najib, 1997). The role of teachers and students is important to ensure that the results of the synthesis of knowledge can be produced.

\section{Step 6: Provide Critical Learning Feedback and Evaluation}

One very important ingredient in active learning is a deep reflection dialogue. This provides students with the opportunity to reflect on the meaning of their learning experiences. One can express reflection on oneself as in a daily journal or in another, as in a class discussion. According to Fink (2003), in reflective writing, students address the following questions: What am I learning? What values do I learn? How do I study? What else do I need to learn? When teachers think about what should happen in teaching and learning, it is important to consider the kind of active learning that can encourage critical thinking.

Teacher's feedback covers aspects such as assessment, comparison of criteria, and student performance standards to evaluate work quality. However, the purpose of feedback is to improve the quality of student learning and performance, rather than for performance grades, and more importantly, it has the potential to help students learn how to evaluate their own performance in the future. Feedback enables teachers and students to engage in dialogue about what distinguishes success and performance from unsuccessful performance as they discuss the criteria and standards (Fink, 2003).

Feedback from students is also an important tool for teaching improvement. Angelo and Cross (1993) proposed several ways to gather important information related to student learning and response to teaching techniques. One of these methods is the two-minute paper method of asking students to identify the most important content to be learned. Teachers can review the comments and use them in their future classes to emphasize the identified issues. Chain notes can be implemented with the envelopes containing key questions in them that students respond by putting their answers in the envelopes. Activities that discuss patterns of response with students can lead to a better teaching and learning.

Teachers need to provide good and adequate feedback to students. The opportunity for students to interact should be considered during the assessment process. Teachers need to provide enough time to help students understand what kind of criteria and standards they mean. Students can also provide feedback and assessment. Each of these techniques helps students learn to distinguish between satisfactory and unsatisfactory performance. The Memory Matrix is also useful in collecting student's feedback; for example, chronological sketches may correspond to different periods of history, and students will be asked to classify the events.

When providing feedback, teachers need to act wisely and meaningfully. According to Wlodkowski and Ginsberg (1995), teachers need to provide informative and non-controlling feedback. The feedback needs to be based on agreed standards, specific and constructive, 
positive, and showing improvement differences over past performances.

The information gathered from student's feedback and assessment is an immediate and important resource for teachers in relation to what is being met, the effectiveness of specific learning activities, and the effectiveness of feedback on standards (Duron et al., 2006). This information should be used to further enhance the course, and may turn out to be very useful from the department or the results-based assessment effort. Finally, it is important to create the final step on the importance of critical evaluation to the seven-step model of formulating facts and generating new ideas and insights.

\section{Step 7: Sparkling Conceptual, Idea and New Solution}

Thinking is the result of mental activity that constantly connects the aspects of rational reason, feeling, and instinct based on the concept of symbiosis that is intertwined with each other. The results can be achieved and can be viewed as follows:

1. The conclusions made are more reliable

2. The decisions made are smarter

3. The things under study can be seen in more depth.

4. The resulting ideas are more creative and innovative (Som \& Dahalan: 2003)

5. All criticism made is more constructive

6. The results created are more artistic that can translate the mood

Pupils cannot be good thinkers if they are not trained in activities that lead to the output as above. Good critical thinking comes from good thinking processes. Students need to be trained and experienced in a variety of processes to move towards good, effective, and sharp thinking in their learning process. Therefore, teachers need to adjust the level of rationality or logic to the level of student education at both the primary and secondary levels. Mysticism is the guiding principle for deciding whether a statement is acceptable or not. In addition, it is also the basis of all knowledge, so long as one does not have a supernatural knowledge, all the learned knowledge cannot be believed to be true, and even raises doubts about the ideas or ideas of the students themselves. Furthermore, mantiks knowledge is closely related to other aspects of knowledge such as creed, sharia, and morals.

After detailing the above steps, the important implications are expected to be the student success and incarceration. This really depends on the teaching skills and attitude of the teacher who integrates the critical thinking elements. In addition, teachers' tendencies are highlighted when their thinking dispositions often emphasized on the critical teaching principles that are integrated into teaching. Swartz (2003), quoted in Marin and Halpern (2011) discusses on the three key principles of teaching critical thinking that reflect the need for both explicit and implicit strategies: a) the more explicit the teaching, the more impact it will have on students; b) the more innovative inquiry activity in classroom will embarking new ideas and incorporates open mindset; c) the more the teaching of thought is integrated and incorporated into the teaching of the content, the more students will think about it and adapt it to its environment. In addition, good student achievement is the result of a critical reflection of teaching, which is to look at new options and not just on one aspect. Assessment is a process involved with problem-solving skills and decision-making such as comparing differences, looking at effects and consequences, 
Vol. 8, No. 4, 2019, E-ISSN: $2226-6348$ @ 2019 HRMARS

evaluating, and so on. Once a person becomes accustomed to this process, this kind of thinking becomes a habit and practice. This is what is expected in the country's education system.

\section{Discussion}

\section{Challenges of Implementing Critical Thinking on Islamic Education Teachers}

After reviewing scholarly evidence and opinions, many agree on the application of critical thinking in teaching. However, there are some complex challenges in implementing critical thinking, especially among Islamic Education teachers. Factors of traditional teacher-centered Islamic teaching, teacher readiness, knowledge and values, and thinking tendencies ( $\mathrm{O}^{\prime}$ hare, 2004) need to be overcome holistically. These barriers do not affect a teacher's knowledge base and resources. However, teachers need to constantly make improvements in any given problem. In this case, teachers need to carefully examine the background of the real and new issue, problem, or concept. If this is not resolved, then there will be a taklid which means accepting something without the support of the argument (al-Ghazali, 1997). Believers will believe, hold, and practice an opinion without any denial or attempt to seek the validity of that opinion. Practicing legacy and taklid practices creates misunderstandings and mental toughness. These people are comfortable with the perspectives and beliefs that do not lead to reform. Disciplined teachers will simply let all of their innovative and critical thinking work, and the element of improvement will not be practiced in teaching and learning.

In the face of the ever-increasing challenges of thinking, logic should be a medium or platform that can filter and at the same time can prevent negative thoughts from circulating in the minds of the people around them. The role of teachers which are equipped with logical knowledge, will be more confident in each idea or theory of thought (Abd \& Rosmawati, 2009). There is a not so hidden prejudice against negative states, and the consequence of avoiding these states is that you inadvertently will stunt our growth, maturity, adventure, and meaning and purpose in life. In conclusion, all the knowledge gained teaches the absolute truth. This can be achieved by evaluating something so that it can manifest the mind to reasonably consider the truth.

\section{Suggestion}

Critical Thinking can strengthen teacher's pedagogical skills and professionalism in Standard Guru Malaysia. Professionalism Teaching in the domain of the profession should enhance the elements of critical thinking as well as creative and innovative thinking. The addition of these features into the domain of the profession is an effort to further enhance the readiness of pre-service teachers who are still in the Teacher Education Institution. In addition, to enhance the soft skills and success in the teacher training which play an important role in structuring the Malaysian teacher standards.

This seven-step framework suggests implementation in the teaching of Islamic education. Details of the implementation process should be outlined in the teacher's lesson plan. This framework is capable of becoming the pathway of best practices in teaching, effective learning environments, assessment-based learning outcomes, and assessment. This clearly shows that the framework can be used as a guide to help students develop critical thinking skills. Through this effort, students and teachers can gain more interesting and effective learning experiences. 


\section{Conclusion}

Based on the discussion, critical thinking needs to be implemented by teachers in teaching Islamic Education. The implementation of critical thinking can be achieved by focusing on seven steps which include planning, questioning, active learning, analysis, research, evaluation and new solutions. Teacher readiness and preparation is concerned and crucial. An outstanding teacher must be a critical thinker in implementation of the jobs and all their responsibilities. Critical thinking-based teaching is in line with the goals outlined in the Malaysian Education Development Plan (PPPM) 2013-2025 (KPM, 2013). In fact, critical thinking can produce the so-called Ulul Albab Generation which can be a contributor to a dynamic and progressive society. In turn, it strives to raise the standards of quality education towards excellence in human civilization.

\section{Corresponding Author}

Asmawati Suhid (PHd), Faculty of Education Studies, University Putra Malaysia, 43400 Serdang, Selangor, Malaysia. Email: asmawati@upm.edu.my

\section{References}

Abdullah, N. U. (1996). Pedoman Pendidikan Anak-anak Dalam Islam. Jilid 1-2. Terjemahan Saifullah Kamalie dan Hery Neor Ali. Kuala Lumpur: Victory Agencie.

Abdullah, N. U. (2012) Tarbiyatul Aulad Fil Islam Terjemahan Arif Rahman. Selangor, Malaysia: Hakim Penerbit Insan Kamil

Alec, P. (2003). Teaching Strategies. Sydney, Australia: The Educational Technology Centre, University of Sydney, Australia. Retrieved March 10, 2003, from http://alex.edfac.usyd.edu.au/BLP/Teaching_Skills/questioning.htm

Al-Ghazali, I. (2007). Bimbingan Mu'minin: pada mencari redha rabbil-'alamin. (terjemahan Syed Ahmad Semait). Singapura: Pustaka Nasional Pte. Ltd.

Ali, M. M. (2012). Islamic Critical Thinking. Selangor, Malaysia: Pearson Malaysia Sdn. Bhd.

Al-Qaradawi, Y. (1996) Al-Aql wa al-Ilm fi al-Qur'an al-Karim Al-Nasyr: Saudi Arabia: Maktabah Wahbah

Al-Qaradawi, Y. (1998) Al-Quran berbicara tentang akal dan ilmu pengetahuan Jakarta: Gema Insani, $277-297$

Anderson, L. W. \& Krathwohl, D. R. (2001). A Taxonomy for Learning, Teaching and Assessing. New York: Longman Publishing.

Angelo, T. A., \& Cross, P. K. (1993). Classroom assessment techniques (2nd ed.). San Francisco: Jossey-Bass.

Asmawati, S., Aderi C. N., Abd. Muhsin, A. \& Khadijah, A. R. (2016) Ke Arah Kecemerlangan Menerusi Pembudayaan Inovasi. Jurnal Teknikal \& Sains Sosial. Bil 6 Jilid 1 Disember 2016 elSSN:2289 7356

Azizi, Y., Noordin, Y., \& Zurihanmi, Z. (2005). Psikologi Kognitif. Skudai. Penerbit Universiti Teknologi Malaysia

Ball, Anna, L. \& Garton, Bryan, L. (2005). "Modelling higher order thinking: The alignment between objectives, classroom discourse, and assessments." Journal of Agricultural 
Vol. 8, No. 4, 2019, E-ISSN: 2226-6348 @ 2019 HRMARS

Education 46(2).

Bonwell, C. C., \& Eison, J. A. (1991). Active learning: Creating excitement in the classroom. ASHEERIC igher Education Report No. 1. Washington, DC: George Washington University.

Carroll, L. \& Leander, S. (2001). Improving student motivation through the use of active learning strategies. Thesis Master of Arts Action Research Project. Saint Xavier University and Skylight Field-Based Master's Program. U.S

Cederblom, J. \& Paulsen, D. (2011). Critical reasoning: understanding and criticizing arguments and theories, 6th edition. Belmont, CA: Wadsworth Publishing.

Chickering, A., \& Gamson, Z. (1987). Seven Principles for Good Practice, AAHE Bulletin, 39(7),3-7.

Clasen, D. R., \& Bonk, C. (1990). Teachers tackle thinking. Madison, WI: Madison Education Extension Program.

David, S. M. (1989). Restructuring Teacher Education Programs for Higher Order Thinking Journal Teacher Education May-Jun

Duron, R., Limbach, B., and Waugh, W. (2006) Critical Thinking Framework for Any Discipline. Husson College Chadron State College International Journal of Teaching and Learning in Higher Education 2006, Volume 17, Number 2, 160-166

Elder, L., \& Paul, R. (1994). Critical thinking: Why we must transform our teaching. Journal of Developmental Education 18(1), 34-35.

Elder, L., \& Paul, R. (1997). Critical thinking: Crucial distinctions for questioning, Journal of Developmental Education, 21(2), 34.

Fink, L. D. (2003). A self-directed guide to designing courses for significant learning.

Fisher, R. (1993) Teaching Children to Think. Cornwall: Simon \& Schuster Education.

Halim, A. T. (2015) Prinsip Pembelajaran Aktif dalam Pengajaran dan Pembelajaran Pendidikan Islam. Jurnal Pendidikan Fakulti Pendidikan, 3(2), 28-42.

Halpern, D. F. (1998). Teaching Critical Thinking for Transfer Across Domains: Disposition, Skills, Structure Training, and Metacognitive Monitoring. American Psychologist, 53, 449-455.

Harris, T., \& Hodges, R. (Eds.). (1995). The Literacy Dictionary. Newark, DE: International Reading Association.

Hashim, R. (2013). Memenuhi Aspirasi Kemahiran Berfikir dalam Pelan Pembangunan Pendidikan Malaysia 2013-2025 menerusi inkuiri dan pedagogi filosofiyyah dalam kalangan guru In Persidangan Majlis Dekan Fakulti Pendidikan (pp. 1-10). Skudai: Universiti Teknologi Malaysia.

Hatcher, D. L., \& Spencer, L. A. (2005). Reasoning and Writing: From Critical Thinking to Composition, 3rd. ed. Boston: American Press.

Hatifah, Y. (2000). Pendidikan Syariah Islamiah: Satu Kajian Tentang Permasalahan Dalam Pengajaran Di Sekolah Agama Dan Harian (KPM) Dan Sekolah Menengah Kerajaan Negeri Di Selangor. Kertas projek Sarjana Pendidikan: UKM http://www.byu.edu/fc/pages/tchlrnpages/Fink/Fink_Article.doc

Kassim, T., Noornajihan, J., Zetty, N. R. (2015). Model Kualiti Guru Pendidikan Islam sebagai Murabbi menurut sarjana Islam. Tinta Artikulasi Membina Ummah 1(1), 101-108,

Krathwohl, D. R. (2002). A revision of Bloom's taxonomy: An overview. Theory into Practice 41(4), p. 212- 218.

Latif, A. M., \& Rosmawati, A. (2009). Pengantar Ilmu Mantik. Kuala Lumpur, Malaysia: Pustaka 


\section{DEVELOPMENT}

Vol. 8, No. 4, 2019, E-ISSN: 2226-6348 @ 2019 HRMARS

Salam Sdn Bhd. ISBN 978-967-975-543-5

Liam, O'. (2004). Measuring Critical Thinking Skills and Dispositions in Undergraduate Students. Thesis submitted to the Faculty of Science and Agriculture of the Queen's University of Belfast.

Maiorana, V. (1991). The road from rote to critical thinking. Community Review, 11, 53-64.

Mayers, C., \& Jones, T. B. (1993). Promoting active learning: Strategies for the college classroom. California, USA: Jossey-Bass Inc

Mohammad, A. A., \& Azmir, M. N. (2012) Metodologi Pengajaran \& Pembelajaran Imam Abu Hanifah: Perbandingan dengan Konsep Pembelajaran Berasaskan Hasil (OBE). Regional Seminar on Islamic Higher Educational Institutions 2012 (SeIPTI 2012) Pusat Pengajian Teras Universiti Sains Islam Malaysia.

Mohd, Z. I. (2014). Islam \& Higher-order Thinking: An Overview. Kuala Lumpur, Malaysia: Penerbit IKIM.

Muhammad, M. A. (2008) Critical Thinking: An Islamic Perspective. Batu Caves, Malaysia: Thinkers Library. $x v+169$

Mulnix, J. W. (2012). Thinking critically about critical thinking. Educational Philosophy and Theory, 44(5), 464-479

Norfadelah, N., \& Ahmad, T. S. (2015) Islamic Theoretical Model for Critical Thinking in Teaching \& Learning of Islamic Education. GSE E-Journal of Education. E-ISSN: 2289-6880 Vol 3 2015.

NorRazah, L. \& Zamri, M. (2007). Peningkatan kualiti penyoalan guru Bahasa Melayu dalam meningkatkan kemahiran berfikir pelajar. Prosiding Seminar Kebangsaan Isu-isu Pendidikan Negara Ketiga, 67-78

Norris, S. P. (1985). Synthesis of research on critical thinking. Educational Leadership, 42(8), 4045.

Paul, R. W., Elder, L., \& Batell, T. (1997). California Teacher Preparation for Instruction in Critical Thinking: Research Findings and Policy Recommendations. Sacramento, CA: California Commission on Teacher Credentialing.

Pott, B. (1994). Strategies for Teaching Critical Thinking. Practical Assessment, Research \& Evaluation, 4 (3).

Raja, J., Siva, S. (2007). Pembestarian Pengajaran dan Pembelajaran. Selangor, Malaysia: Mahir Holding Sdn Bhd.Shah Alam.

Retrieved on October 28, 2004, from

Som, H. N. \& Mohamad, D. M. R. (1998) Kemahiran Berfikir Secara Kritis dan Kreatif (KBKK) Selangor: Pearson Malaysia Sdn. Bhd.

Sorunke, O.A. (2018). Forensic Accounting Investigation Techniques and Successful Prosecution of Corruption Cases in Nigeria, International Journal of Academic Research in Accounting, Finance and Management Sciences 8 (3): 37-44.

Tan, S. Y., \& Halili, S. H. (2015). Effective Teaching of Order Higher Thinking (HOT) in Education. The Online Journal of Distance Education and E-Learning, 3(2), 41-47.

Unit Pelaksanaan \& Prestasi Pendidikan (PADU). (2015). Buletin Anjakan KPM Bil 5/2015. Retrieved from http://www.padu.edu.my/files/Buletin_Anjakan_Bil_5-2015_(Final).pdf

Wlodkowski, R., \& Ginsberg, M. (1995). Diversity and motivation. San Francisco: Jossey-Bass. 
Yahya, H., Razali, A. B., \& Baki, R. (2018). To Tell or Not to Tell: Exploring Malaysian Teachers' Perceptions towards Storytelling in English Classrooms. International Journal of Academic Research in Progressive Education and Development, 7(4), 303-323.

Yahya, O. (2014). Peranan Guru Bahasa Melayu Dalam Merangsang Kemahiran Berfikir Aras Tinggi (KBAT). Dewan Bahasa, 14(25), 20-24

Yee, M. H., Jailani, M. Y., Widad, O., Razali, H., Kiong, T. T. (2010) Penggunaan Kemahiran Berfikir Aras Tinggi Marzano dalam Penjanaan Idea. Proceedings of The 3rd Regional Conference on Engineering Education \& Research In Higher Education 2010. Skudai, Johor: Universiti Teknologi Malaysia (UTM).

Zainoriah, K. (2015). Elemen Pemikiran Kritis Menurut Perspektif al Quran: Kajian Surah Al Rum. Tesis Tidak Diterbitkan Ijazah Doktor Falsafah, Jabatan Akidah dan Pemikiran Islam, Akademi Pengajian Islam, Universiti Malaya, Kuala Lumpur

Zamri, \& Norazah, L. (2011) Kepelbagaian kaedah Penyoalan Lisan dalam Pengajaran Guru Bahasa Melayu: Kaedah Pemerhatian. Jurnal Pendidikan Bahasa Melayu Vol. 1, Bil. 1 (Mei 2011): 51-65

Zhaffar, M. N., Hamzah, M. I., Razak K. A. (2016) Matlamat Pengajaran Berfikir Kritis Menurut Guru Pendidikan Islam. Technical \& Social Science Journal, 6(1), Dis 2016 elSSN:2289 7356 